\title{
(1) \\ KUALITAS MINYAK GORENG SEBELUM DAN SESUDAH DIPAKAI DITINJAU DARI KANDUNGAN ASAM LEMAK BEBAS DAN PERUBAHAN WARNA
}

\author{
Husnah $^{1)}$, Nurlela ${ }^{2)}$, Agus Wahyudi (3) \\ ${ }^{1)}$ Dosen PNSD dpk Program Studi Teknik Kimia Universitas PGRI Palembang \\ ${ }^{2}$ Dosen DTY Program Studi Teknik Kimia Universitas PGRI Palembang \\ ${ }^{3)}$ Dosen DTY Program Studi Teknik Kimia Universitas PGRI Palembang \\ email : husnahpgri@gmail.com \\ email : nurlela@univpgri-palembang.ac.id \\ email : aguswahyudi@univpgri-palembang.ac.id
}

\section{Abstrak}

Kelapa sawit adalah komoditi sehingga dapat menghasilkan devisa untuk negara karena kelapa sawit adalah salah satu sumber nabati (dari tumbuhan) selainberbagai jenis kacang, jangung dan yang lainnya. Minyakbwrasal dari kelapa sawit banyak dipergunakan untuk pembuatan minyak goreng bersumber dari daging buah serta inti sawit.Sampai saat ini pabrik minyak kelapa sawit cukup berkembang untuk menghasilkan hasilyang sangat baik untuk konsumen karena minyak yang dihasilkan terlebih dahulu dianalisa di laboratorium khusus, sehingga minyak yang akan dipasarkan sesuai dengan standar dan pengawasan mutu minyak kelapa sawit.Dalam mengamati kualitas minyak yang berasala dari kelapa sawit setelah pemakaian berulang tersebut antara lain dengan melakukan analisa perbandingan Asam Lemak Bebas (FFA) dan warna terhadap kualitas minyak sebelum dan sesudah dipakai.

Kata Kunci: Minyak goreng, pemakaian berulang, Asam Lemak Bebas, dan perubahan warna

\section{PENDAHULUAN}

Kelapa sawit (Elacis guuinensies jack), adalah tanaman daerah panas termasuk pada Famili Palmea yang bermula kawasan Negeria di sepanjang pantai Guinea. Kelapa sawit adalah tumbuhan yang memiliki nilai ekonomi sangat tinggi sebab menjadi contoh tumbuhan pemasok minyak tumbuhan.

Minyak yang berasal dari sawit merupakan minyak lemak separuh padat memiliki susunan tidak berubah. Minyak sawit tersusun dari fraksi (wujud) cair dan padat. susunan wujud padat berstruktur asam lemak-jenuh, sperti: Asam Palmintat, Asam Stearat serta Asam Miristat. Untuk wujud cair berpola dengan asam-lemak tidak jenuh tersusun atas Asan Linoleat serta Asam Oleat.

Penggunaan minyak goreng oleh konsumen pada umumnya dilakukan secara berulang dengan alasan penghematan (nilai ekonomis). Pada waktu panjang menggunakan minyak goreng dengan terus menerus sehingga mengakibatkan rusaknya minyak goreng, Mulasari dan Utami, 2012). Rusaknya minyak goreng pada waktu penggorengan sehingga berpengaruh pada nilai gizi serta kualitas pada makanan yang kita goreng.

Minyak goreng curah biasanya pendistribusiannya secara langsung tanpa dibungkus higienis sehingga mengakibatkan terpapar banyak udara. Minyak gorengcurah banyak digunakan pedagang 
pinggiran ataupun pada rumah tangga yang dipergunakan secata terus-menerus atau berulang kali, sehingga menyebabkan banyak reaksi oksidasi (Prasetyawan, 2007; Aminah dan Isworo, 2009). Kandungan asam lemak bebas dan perubahan warna bisa menjadi parameter penurunan mutu minyak goreng. Penggunaan minyak goreng curah oleh masyarakat umumnya secara berulang sehingga diperlukan riset kadar minyak goreng curah sebelum ataupaun sesudah dipergunakan secara terus-menerus, terutama pada tolak ukur untuk kandungan asam lemak bebas dan perubahan warna.

\section{TINJAUAN PUSTAKA}

\section{- Minyak Kelapa Sawit}

Kelapa sawit terbagi menjadi serabut kelapa sawit serta inti sawit. CPO atau Crude Palm Oil minyak kelapa sawit bersumber pada serabut kelapa sawit sedangkan Palm Kernel Oil (PKO), berasal pada inti sawit. Minyak dari inti sawit terutama dimanfaatkan untuk subtitusi berasal pada minyak kelapa sawit, sebab komponen penyusunnya sama/mirip dgn minyak kelapa pada umumnya.

Keunggulan minyak kelapa sawit dibanding dengan minyak goreng lain adalah:

1. Minyak sawit mengandung tokoferol berfungsi sebagai sumber vitamin $\mathrm{E}$.

2. Ketetapan kalor tekanan tinggi serta tidak mudah teroksidasi sehingga minyak kelapa sawit tidak mudah rusak

\section{- Lemak dan Minyak}

Lemak serta minyak mewujudkan zat-zat yg bersumber pada tumbuh-tumbuhan serta hewan. Lemak hewani memiliki banyak sterol dan disebut kolestrol, sementara lemak yang berasal dari tumbuhan (nabati) memiliki kandungan fitosterol dan terbanyak menyimpan asam lemak tak jenuh akhirnya baiasanya terbentuk zat cair. Lemak yang berasal dari tumbuhan (nabati) dengan wujud cairan terdiri dariu 3 bagian, seperti:

1. Drying oil hendak terbentuk lembaran kertas jika dikeringkan pada udara contoh minyak yang bergunan bagi pernis atau cat.

2. Semi drying oil misalnya: kembang matahari, biji kapas yang berminyak serta minyak yang terdapat dalam jagung

3. Non drying oil misalnya: minyak kacang tanah, minyak kelapa serta Lemak yang berasal dari tumbuhan terbentuk berwujud padat contohnya minyak coklat serta bagian "stearin" berasal minyak sawit.

\section{- $\quad$ Sifat Fisika Minyak dan Lemak}

\section{Bau dan Rasa}

Bau dan rasa CPO (Crude Palm Oil) ada yang disebabkan secara alami dan ada juga yang disebabkan oleh terbentuknya asamberantai yang tidak panjang sebagai produk pembelahan yang menyebabkan kerusakan pada lemak maupun minyak. Biasanya bau atau rasa dikarenakan dari bau karoten.

\section{Kelarutan}

Minyak kelapa sawit tidah bercampur diair , tapi sedikit terlarut dialkohol serta terlarut semua dalm etil-eter, karbon disulfida serta halogen (golongan VIIa) pelarut.

\section{Titik Didih}


Makin banyak rantai-karbon asam lemak penyusun minyak kelapa sawit maka titik didih semakin meningkat dan bila ikatan rangkapnya semakin banyak maka titik didihnya semakin rendah.

4. Indeks Bias (Derajat Penyimpanan Cahaya)

Indeks bias menaik di minyak kelapa sawit dengan memiliki rantai karbon yang-banyak, berikatan rangkap serta akibat dari meningkatnya bobot molekul dan derajat kejenuhan.

\section{- Sifat Kimia Minyak dan Lemak}

\section{Hidrolisa}

Pada reaksi-hidrolisa lemak ataupun minyak berubah jadi asam lemak tidak terikat atau gliserol. Reaksi ini berdampak keruakan minyak maupun lemak sehingga menyebabkan ketengikan

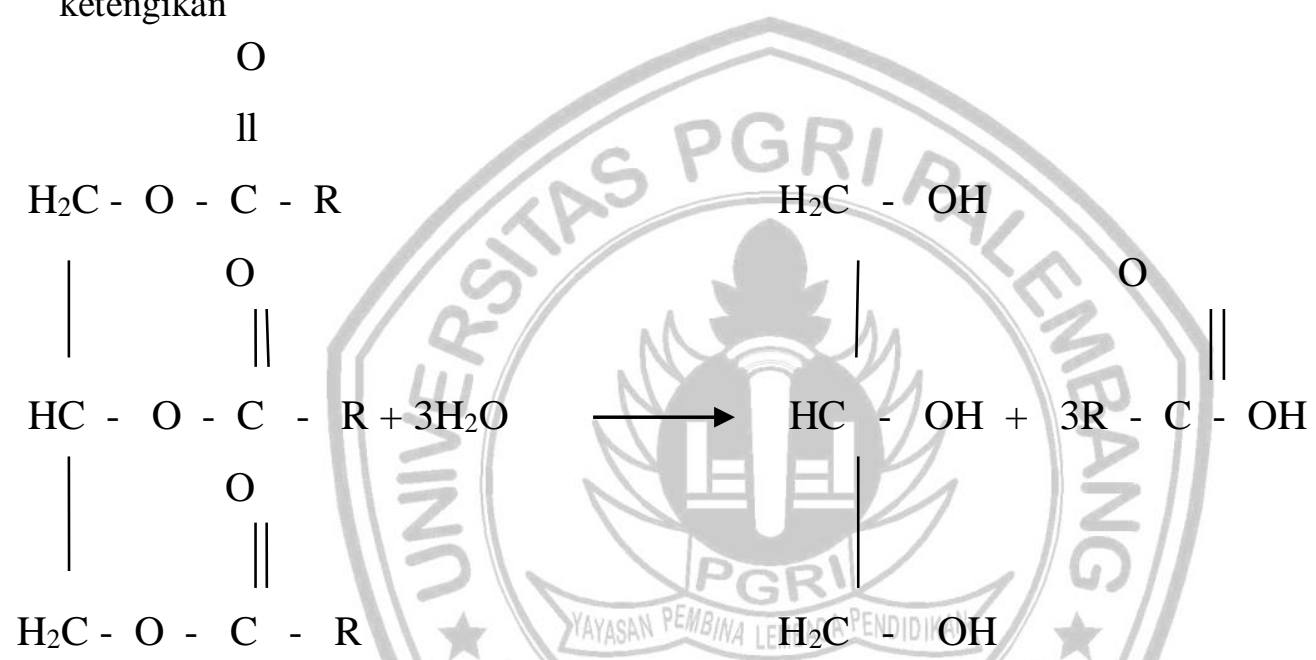

\section{Oksidasi}

Reaksi ini dapat terjadi bila kontak diantara oksigen serta lemak ataupun minyak sehingga menyebabkan ketengikan. Oksidasi ini bermula dari terbentukannya peroksida serta hidroperoksida, terurai menjadi asam lemak berbarengan pada perubahan hidroperoksida jadi aldehid, keton atau asam-lemak tidak terikat.

$$
\mathrm{R} 1-\mathrm{CH}_{2}-\mathrm{CH}=\mathrm{CH}-\mathrm{CH}_{2} \longrightarrow \mathrm{R} 1-\mathrm{CH}_{2}-\mathrm{CH}-\mathrm{CH}-\mathrm{R}_{2}-\mathrm{H}
$$

Asam lemak tidak jenuhRadikal bebasHidrogen yang tidak stabil

$$
\begin{array}{l|c} 
& \mathrm{R}_{1}-\mathrm{CH}-\mathrm{CH}-\mathrm{CH}=\mathrm{CH}_{2}-\mathrm{R}_{2} \\
\mathrm{R}_{1}-\mathrm{CH}_{2}-\mathrm{CH}-\mathrm{CH}-\mathrm{CH}_{2}-\mathrm{R}_{2} & \\
\text { Peroksida aktif } & \downarrow
\end{array}
$$

\section{Peroksida aktif}

$$
\mathrm{R}_{1}-\mathrm{CH}-\mathrm{CH}=\mathrm{CH}-\mathrm{CH}_{2}-\mathrm{R}_{2}+\mathrm{R}_{1} \mathrm{CH}-\mathrm{CH}=\mathrm{CH}-\mathrm{CH}_{2}-\mathrm{R}_{2}
$$




\section{Hidroperoksida Radikal tidak terikat atau bebas}

\section{Esterifikasi}

Proses ini bermaksud menukar asam-lemak berasal pada trigliserida berbentuk ester.

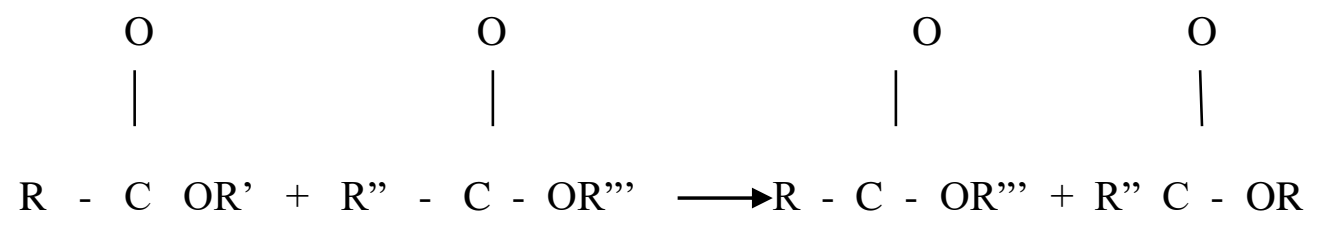

Adapun sifat minyak kelapa sawit sebelum serta sesudah dimurnikan terlihat pada Tabel 1.

Tabel 1. Sifat minyak kelapa sawit sebelum serta sesudah dimurnikan

\begin{tabular}{|l|c|c|}
\hline \multicolumn{1}{|c|}{ SIFAT } & MINYAK SAWIT & MINYAK SAWIT MURNI \\
\hline Titik cair Awal $\left({ }^{\mathbf{0}} \mathbf{C}\right)$ & $21-24$ & 29,4 \\
\hline Titik cair Akhir $\left.\mathbf{(}^{\mathbf{0}} \mathbf{C}\right)$ & $26-29$ & 40,0 \\
\hline $\begin{array}{l}\text { Bobot Jenis } \mathbf{1 5}^{\mathbf{0}} \mathbf{C} \\
\text { (gr/ml) }\end{array}$ & $0,859-0,870$ & - \\
\hline Indeks bias pada 40oC & $36,0-37,5$ & $46-49$ \\
\hline $\begin{array}{l}\text { Bilangan } \\
\text { Penyambungan } \\
\text { (mgKOH / gr } \mathbf{m i n y a k})\end{array}$ & $14,5-19,0$ & $196-206$ \\
\hline $\begin{array}{l}\text { Bilangan Iod } \mathbf{( g r} \text { Iod/1 } \\
\text { kg lemak) }\end{array}$ & & \\
\hline
\end{tabular}

- Komposisi Asam Lemak Minyak Kelapa Sawit

Minyak dari kelapa sawit komponen utamanya yaitu trigliserida.Trigliserida yaitu turunan gliserol dari ke-3 gugus - $\mathrm{OH}$ diubah menjadi asam lemak.
$\mathrm{H}-\mathrm{C}-$ Fartty acid

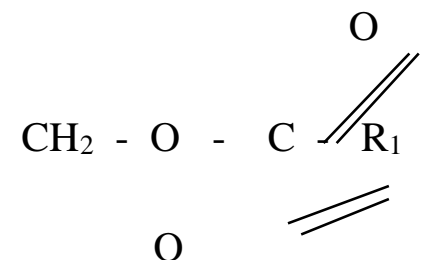
H - C - Fartty acid
$\mathrm{CH}-\mathrm{O}-\mathrm{C}-\mathrm{R}_{2}$
H - C - Fartty acid
O
$\mathrm{CH} 2-\mathrm{O}-\mathrm{C}-\mathrm{R}_{3}$
$\mathrm{H}$

Gambar 1. Gliserol dan Triglesida 
Kandungan Asam lemak didalam triglesida terdiri dari asam lemak tak jenuh (unsaturated fatty acid) serta asam lemak jenuh (saturated fatty acid). Asam lemak-jenuh (saturated fatty acid) merupakan asam lemak dimana rantai karbonnya dijenuhi dengan hidrogen, minyak yang mengandung ikatan diatas ini sulit mengikat gugus fungsi lainnya bila dilakukan reaksi substitusi, karena mempunyai ikatan atom tunggal. (unsaturated fatty acid) atau Asam lemak tak jenuh merupakan asam lemak dengan rantai karbonnya tak terjenuhi dari $\mathrm{H}_{2}$ (hidrogen) atau memiliki satu ikatan ganda dua atau berlebih

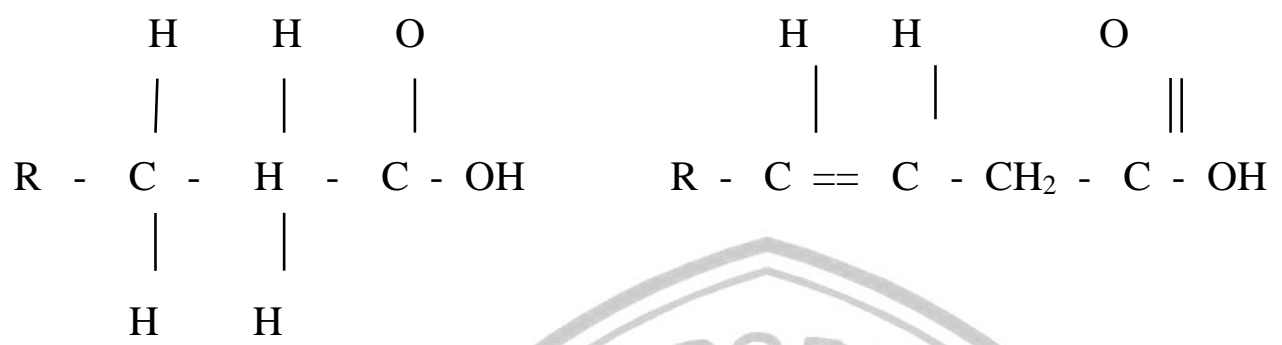

Gambar 2. Asam lemak tak jenuh serta Asam lemak jenuh

Berdasarkan kandungan asam lemak tijak jenuh serta jenuh dibedakan mejadi fraksi olein, fraksi strearin dan asam lemak (asam lemak tak terikat atau free fatty acid dimanfaatkan untuk bahan pembuatan sabun serta grease)

Adapun kandungan Asam lemak terdapat diminyak Kelapa Sawit serta inti-sawit dapat dilihat ditabel 2.

Tabel 2. Komposisi asam lemak dalam minyak kelapa sawit dan inti sawit

\begin{tabular}{|l|c|c|}
\hline \multicolumn{1}{|c|}{ ASAM LEMAK } & $\begin{array}{c}\text { MINYAK KELAPA } \\
\text { SAWIT (\%) }\end{array}$ & $\begin{array}{c}\text { MINYAK INTI SAWIT } \\
\text { (\%) }\end{array}$ \\
\hline Asam Lemak Jenuh & & $3-4$ \\
1. Asam Kaprilat $\left(\mathrm{CH}_{3}\left(\mathrm{CH}_{2}\right) 6 \mathrm{COOH}\right.$ & - & $3-7$ \\
2. Asam Kaproat $\left(\mathrm{CH}_{3}\left(\mathrm{CH}_{2}\right)_{4} \mathrm{COOH}\right.$ & 1 & $41-55$ \\
3. Asam Laurat $\left(\mathrm{CH}_{3}\left(\mathrm{CH}_{2}\right) \mathrm{COOH}\right)$ & $14-19$ \\
4. Asam Miristat $\left(\mathrm{CH}_{3}\left(\mathrm{CH}_{2}\right) 12 \mathrm{COOH}\right.$ & $4-10$ & $1-4$ \\
5. Asam Stearat $\left(\mathrm{CH}_{3}\left(\mathrm{CH}_{2}\right) 16 \mathrm{COOH}\right)$ & $38-50$ & $10-20$ \\
\hline Asam Lemak Tidak Jenuh & $5-14$ & $1-5$ \\
1. Asam Oleat $\left(\mathrm{CH}_{3}\left(\mathrm{CH}_{2}\right)_{7} \mathrm{COOH}\right.$ & 1 & $1-5$ \\
2. Asam Linoleat $\left(\mathrm{CH}_{3}\left(\mathrm{CH}_{2}\right)_{4} \mathrm{CH}=\mathrm{CH}\right)$ & & \\
3. Asam Linolenat $\left(\mathrm{CH}_{-} \mathrm{CH}_{(\mathrm{CH}}\right)_{7} \mathrm{COOH}$ & & \\
\hline
\end{tabular}

Sebagian besar masyarakat mempergunakan minyak goreng dalam pengolahan pangan. Sebab masyarakat beranggapan bahwa makanan lebih berasa enak apabila digoreng (Bangun,D,Memoar, 2010). Semua pabrik minyak goreng berlomba-lomba dalam mengiklankan produk mereka dan menganggap bahwa produk mereka menyehatkan, terbaik serta mengandung vitamin-vitamin seperti A, E,D Omega3 serta Omega9. Serta menganggap bahwa produk mereka tidak terdapat kolestrol karena melewati proses penyaringan sebanyak dua kali. Asam lemak jenuh serta asam lemak tidak jenuh merupakan kandungan dari minyak sawit. Komposisi asam lemak tidak jenuh menyebabkan semakin tinggi hal ini terjadi karena cara pemisahan minyak kelapa sawit melalui 2 kali proses 
pemisahan susunan lemak-jenuh. Minyak mudah rusak pada saat kita panaskan berkelanjutan dan dengan temperatur tinggi dan bercampur dengan oksigen pada udara bebas menyebabkan sering terjadi reaksi oksidasi minyak hal ini terjadi karena besarnya komposisi asam lemak tidak jenuh.

Kualitas minyak setelah digunakan akan menurun bila kita menggoreng dengan suhu sangat tinggi yaitu $\left(160^{\circ} \mathrm{C}-180^{\circ} \mathrm{C}\right)$ secara berkelanjutan. Menggunakan suhu tinggiselama penggorenganmemacu terjadinya oksidasi minyak. Menurut Bangun,D (2010) setiap peningkatan suhu $10^{\circ} \mathrm{C}$ lajukecepatanoksidasi meningkatduakali lipat. Dengan suhu rendah menyebabkan berkurangnya oksidasi lemak dan menaiknya oksidasi lemak bila suhu ditinggikan

Kerusakan minyak akan mempengaruhi kualitas dannilaigizimakananyang digoreng.Minyak goreng dipanaskan dengan suhu yang tinggi akanmenyebabkansebagianminyak teroksidasi. Minyak kadar luarsa akibatproses oksidasiakan menghasilkanmakananberwarnakurang menarik danrasayang tidak enak,sertakerusakanbeberapa vitamindanasam lemakesensialdidalam minyak. Proses oksidasitersebut terjadisaatminyaktersebut mengalami kontak dengan sejumlah oksigen. Reaksioksidasi jugaakanmenimbulkan bau tengik padaminyak danlemak (Ketaren, S. 1986).Selainmenimbulkan aroma tidak sedap, dapat menyebabkan racun akibatoksidasiyang mempunyaidampakmerusak cseldan jaringantubuh.Halinidisebabkanradikal bebasbersifatsangatreaktif(Retno, G, 1995).

Minyakgoreng yang dipakaioleh rakyat luas wajib memenuhi ketentuan atau memiliki dasar ketentuan yang telah diatur seperti padaTabel1 di bawah ini :

Tabel.3 Syarat Mutu Minyak Goreng

\begin{tabular}{|c|c|c|}
\hline KRITERIA UJI & SATUAN & SYARAT \\
\hline Keadaaan bau, warna dan rasa & & Normal \\
\hline Air & $\% \mathrm{~b} / \mathrm{b}$ & Maks 0,30 \\
\hline $\begin{array}{l}\text { Asam lemak bebas (dihitung } \\
\text { sebagai asam laurat) }\end{array}$ & & Maks 0,20 \\
\hline $\begin{array}{l}\text { Bahan makanan } \\
\text { tambahan }\end{array}$ & $\begin{array}{r}\text { Sesuai } \\
\text { No } \\
\end{array}$ & $\begin{array}{l}\text { Permenkes } \\
\text { /IX/88 }\end{array}$ \\
\hline $\begin{array}{l}\text { Cemaran Logam: } \\
\text { - Besi }(\mathrm{Fe}) \\
\text { - Tembaga }(\mathrm{Cu}) \\
\text { - Raksa }(\mathrm{Hg}) \\
\text { - Timbal }(\mathrm{Pb}) \\
\text { - Timah }(\mathrm{Sn}) \\
\text { - Seng }(\mathrm{Zn})\end{array}$ & $\begin{array}{c}\mathrm{Mg} / \mathrm{kg} \\
\quad, \\
\quad, \\
\quad, \\
\quad, \\
\text {, }\end{array}$ & $\begin{array}{c}\text { Maks } 1,5 \\
\text { Maks 0,1 } \\
\text { Maks 0,1 } \\
\text { Maks 40,0 } \\
\text { Maks 0,005 } \\
\text { Maks 40,0/250,0)* }\end{array}$ \\
\hline Arsen (As) & $\% \mathrm{~b} / \mathrm{b}$ & Maks 0,1 \\
\hline Angka Peroksida & $\% \mathrm{mg} \mathrm{02/gr}$ & Maks 1 \\
\hline
\end{tabular}

Sumber: Departeman Perindustrian (SNI 01-3741-1995) [9]

*) Dalam kemasan kaleng

Penggunaan minyak-goreng dengan terus-menerus harus menjadi perhatian kita karena memang dari segi ekonomi sangat menguntungkan. Tetapi dari segi kesehatan sangatlah berbahaya bagi tubuh kita. Ada beberapa penelitian telah memperlihatkan bahaya lemak-makan yang teroksidasi 
bagi tubuh manusia dan juga pada hewan penelitian. Oksidasi-minyak mengeluarkan oxygen-derived free radicals serta hasil hidroksilasi sehingga jadi FFA, aldehida atau keton dengan menginduksi racun di tubuh. Oksidatif yang berasal dari memanaskan minyak menjadi memodulasi peroksidasi lipid serta kadar lipoprotein, akan meningkatkan kandungan kolesterol total, LDL, TG, asam lemak-bebas, fosfolipid serta serebrosida seraya menurunkan kandungan HDL.

Pemaparan temperatur yang sangat tinggi serta oksigen diminyak goreng dapat menyebabkan reaksi-oksidasi berlangsung. Yang menjadi sejumlah tolak ukur untuk penyebab oksidasi misalnya free fatty acid (FFA), susunan polar, asam-konjugat di-enoat menaik disetiap penggorengan yang berulang-kali pada 60 kali priode penasan/penggorengan (Yoon dan Choe, 2007).

\section{METODOLOGI PENELITIAN}

\section{- Preparasi Minyak}

1. Minyak goreng kita gunakan untuk bahan penelitian/analisa sebelumnya kita bagi jadi tiga bagian yaitu sebelum pemakaian, pada saat menggorengan ikan serta dipergunakan menggoreng tempe.

2. Selanjutnya kita pisahkan yang kita pakai untuk menggoreng ikan serta tempe (sebanyak 3 kali goreng), lalu minyak itu teliti dilaboratorium

\section{- Analisa Free Fatty Acid (FFA)}

1. Menimbang sampel ke dalam erlenmeyer.

2. Ditambahkan pelarut $50 \mathrm{ml}$ pelarut alkohol Teknis/ Isoprophyl Alkohol yang telah dinetralkan ke erlenmeyer yang telah berisi sampel dan pastikan sampel telah larut sempurna sebelum titrasi, panaskan.

3. Titrasi sample tersebut dengan $\mathrm{NaOH}$ sambil diaduk sampai warna berubah menjadi warna merah muda,warna tersebut harus tidak berubah selama 30 detik.

4. Hasil analisa yang didapat dibuat report sesuai dengan keperluan.

5. Menghitung $\%$ FFA

$$
\% F F A=\underline{N} \times 1 \times 25,6
$$

Keterangan :

$\begin{array}{ll}\mathrm{N} & =\text { Normalitas } \\ \mathrm{V} & =\text { Volume larutan } \mathrm{NaOH} \text { yang terpakai dalan titrasi } \\ \mathrm{W} & =\text { Berat sampel minyak } \\ 25,6 & =\text { Asam Palmitat }\end{array}$


- Analisa Warna

1. Sampel dipanaskan

2. Sampel dituangkan kedalam Lovibond Cell ( untuk sample Refined Oil digunakan Lovibond Cell 5 1/4 inchi dan BPO gunakan Lovibond Cell 1 inchi).

3. Tempatkan Lovibond Cell yang berisi sample kedalam Kalorimeter dan atur skala merah dan kuning dari standar agar sama dengan warna dari sample minyak, amati sample dan standar melalui lensa, gunakan 10 satuan kuning dan 1 satuan merah.

- Diagram Alir

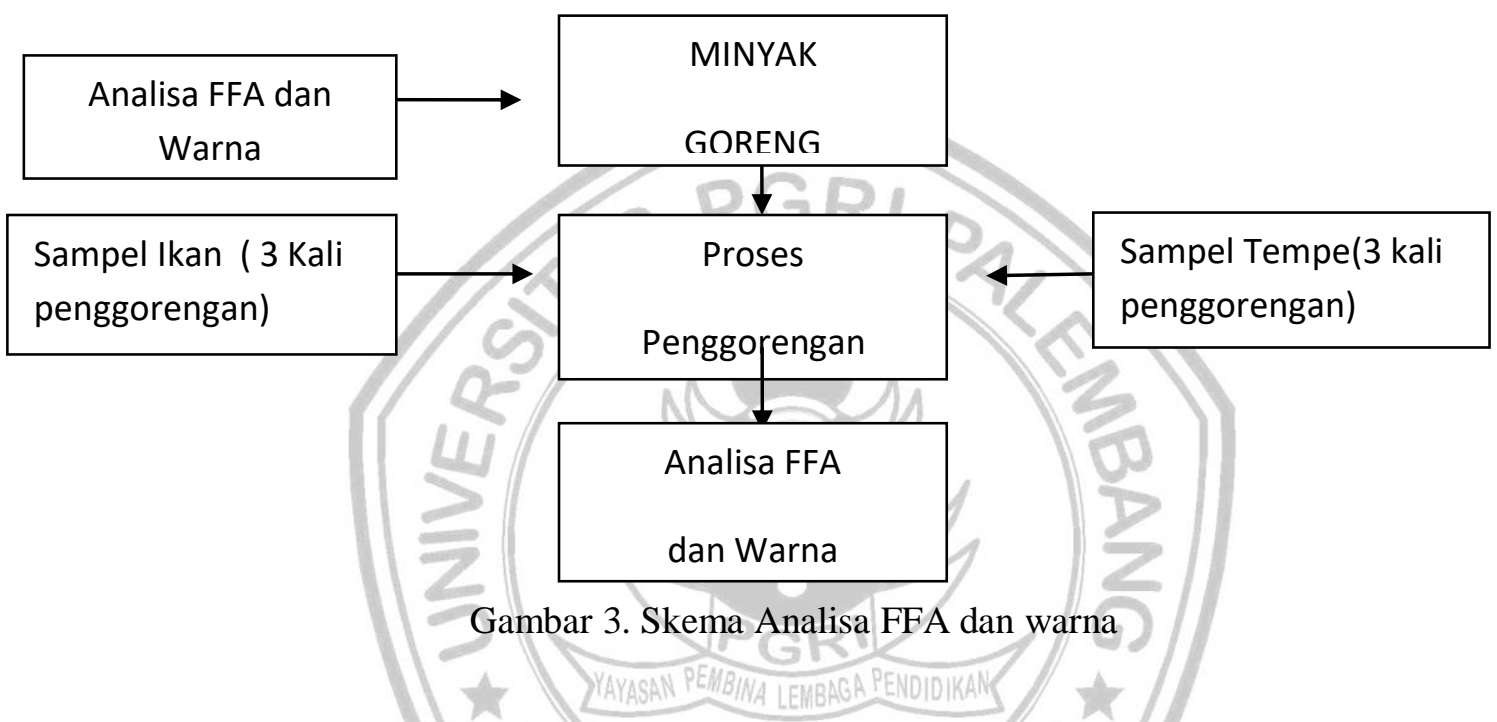

HASIL DAN PEMBAHASAN

\section{Hasil Penelitian}

* Minyak sebelum dipakai

\section{- Analisa FFA}

Diketahui : $\mathrm{W}=10,6896 \mathrm{grV}=4,67 \mathrm{ml}$

$$
\mathrm{N}=0,0115 \mathrm{~mol} / \mathrm{ml}
$$

Jadi :

$$
\mathrm{FFA}=\frac{0,0115 \mathrm{~mol} / \mathrm{ml} \times 4,67 \mathrm{ml} \times 25,6 \mathrm{~g} / \mathrm{mol}}{10,6896 \mathrm{gr}}=0,128 \%
$$

\section{- Analisa Warna}

Dari Analisa warna didapat nilai : $2.4 \mathrm{r}-24 \mathrm{y}$

\section{Minyak sudah dipakai menggoreng}




\section{Sampel ikan}

\section{a. Sampel ikan pertama}

- Analisa FFA

Diket : $\quad \mathrm{W}=11,2819 \mathrm{grV}=6,29 \mathrm{mlN}=0,0115 \mathrm{~mol} / \mathrm{ml}$

Perhitungan :

$$
\mathrm{FFA}=\frac{0,0115 \mathrm{~mol} / \mathrm{ml} \times 6,29 \mathrm{ml} \times 25,6 \mathrm{~g} / \mathrm{mol}}{11,2819 \mathrm{gr}}=0,164 \%
$$

\section{- Analisa Warna}

Dari Analisa warna didapat nilai : $4.8 \mathrm{r}-48 \mathrm{y}$

\section{b. Sampel ikan kedua}

\section{- Analisa FFA}

Diketahui : $\mathrm{W}=12,4012 \mathrm{gr}$

$$
\begin{aligned}
\mathrm{V} & =8,27 \mathrm{ml} \\
\mathrm{N} & =0,0115 \mathrm{~mol} / \mathrm{ml}
\end{aligned}
$$

Jadi :

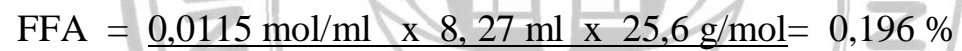

$$
12,4012 \mathrm{~g}
$$

\section{- Analisa Warna}

DariAnalisa warna didapat nilai : $4.7 \mathrm{r}-67 \mathrm{y}$

\section{c. Sampel ikan ketiga}

- Analisa FFA

Diketahui : $\quad \mathrm{W}=10,7402 \mathrm{gr}$

$$
\begin{aligned}
\mathrm{V} & =9,50 \mathrm{ml} \\
\mathrm{N} & =0,0115 \mathrm{~mol} / \mathrm{ml}
\end{aligned}
$$

Perhitungan :

$$
\mathrm{FFA}=\frac{0,0115 \mathrm{~mol} / \mathrm{ml} \times 9,50 \mathrm{ml} \times 25,6 \mathrm{~g} / \mathrm{mol}=0,260 \%}{10,7402 \mathrm{gr}}=0
$$

\section{Analisa Warna}

DariAnalisa warna didapat nilai : $7.1 \mathrm{r}-71 \mathrm{y}$

\section{Sampel tempe}

- Sampel tempe pertama

\section{- Analisa FFA}

Diketahui : $\quad \mathrm{W}=11,2750 \mathrm{gr} \mathrm{V}=5,99 \mathrm{ml} \mathrm{N}=0,0115 \mathrm{~mol} / \mathrm{ml}$ Jadi : 


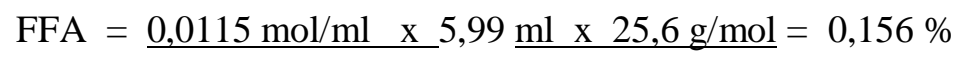

11,2750 gr

- Analisa Warna

Dari Analisa warna didapat nilai : $3.9 \mathrm{r}-39 \mathrm{y}$

\section{- Sampel tempe kedua}

- Analisa FFA

Diketahui : $\mathrm{W}=11,0514 \mathrm{gr}$

$\mathrm{V}=6,79 \mathrm{ml}$

$\mathrm{N}=0,0115 \mathrm{~mol} / \mathrm{ml}$

Jadi :

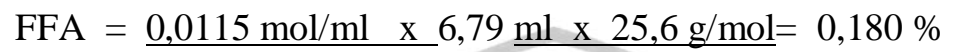
$11,0514 \mathrm{~g}$

\section{- Analisa Warna}

DariAnalisa warna didapat nilai : $5.8 \mathrm{r}-58 \mathrm{y}$

\section{- Sampel tempe ketiga}

- Analisa FFA

Diketahui : $\mathrm{W}=10,0719 \mathrm{gr}$

$$
\begin{aligned}
\mathrm{V} & =9,55 \mathrm{ml} P \mathrm{P} \\
\mathrm{N} & =0,0115 \mathrm{~mol} / \mathrm{ml}
\end{aligned}
$$

Jadi :

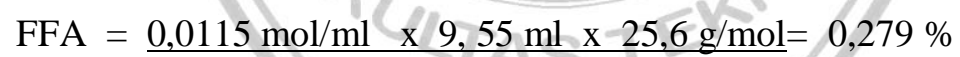
$10,0719 \mathrm{gr}$

- Analisa Warna DariAnalisa warna didapat nilai : $6.2 \mathrm{r}-62$ y

\section{PEMBAHASAN}

Dari hasil penggorengan dan kestabilan menyimpan dengan baik akan menghasilkan menggoreng yang baik pada temperatur rendah. Meskipun menggunakan temperatur rendah akan menghasilkan mutu gorengan yang baik, tetapi dengan alasan ekonimis sehingga sedikit dipraktekkan. Karena menggoreng dengan menggunakan temperatur yang tinggi memakan waktu yang singkat dan biaya relatif murah.

Alasan yang harus dipertimbangkan dalam memilih temperatur penggorengan untuk menghasilkan hasil yang optimal adalah warna bahan makanan yang kita goreng. Selain itu temperatur tinggi berakibat denaturisasi pada bahan makanan, yang utama adalah daging, jadi mengeluarkan bahan makanan yang warnanya serta rasa yang kurang disenangi. 
Karena itu, dilakukan percobaan terhadap 2 parameter kualitas minyak goreng yaitu FFA dan warna. Hasil percobaan terhadap uji FFA dan warna dapat kita lihat ditabel 4 berikut ini:

Tabel 4. Perhitungan hasil analisa FFA dan warna minyak sebelum dan sesudah dipakai berulang pada penggorengan ikan dan tempe

\begin{tabular}{|l|c|c|}
\hline \multicolumn{1}{|c|}{ JENIS SAMPEL } & FFA & WARNA \\
\hline Sebelum dipakai & $\mathbf{0 , 0 9}$ & $\mathbf{2 , 4} \mathbf{r}-\mathbf{2 4} \mathbf{~ y}$ \\
\hline Sesudah dipakai : & $0,164 \%$ & $4.8 \mathrm{r}-48 \mathrm{y}$ \\
- Menggoreng ikan ke-1 & $0,196 \%$ & $6.7 \mathrm{r}-67 \mathrm{y}$ \\
- Menggoreng ikan ke-2 & $0,260 \%$ & $7.1 \mathrm{r}-71 \mathrm{y}$ \\
- Menggoreng ikan ke-2 & 0,156 & $3.9 \mathrm{r}-39 \mathrm{y}$ \\
& & $5.8 \mathrm{r}-58 \mathrm{y}$ \\
- Menggoreng tempe ke-1 & 0,180 & $6.2 \mathrm{r}-62 \mathrm{y}$ \\
- Menggoreng tempe ke-2 & 0,279 & \\
\hline - Menggoreng tempe ke-3 & & \\
\hline
\end{tabular}

Mutu FFA minyak goreng standard yang telah ditentukan adalah sebesar 0,20\% dan pada uji FFA yang dilakukan terhadap minyak goreng dengan sampel ikan didapat bahwa yang memenuhi standar adalah pada penggorengan ke-1 dan ke-2 saja. Sedangkan uji FFA pada minyak goreng pada sampel tempe ternyata sama hanya memenuhi standar pada penggorengan ke-1 dan ke- 2 juga.

Standar warna pada minyak goreng yang ditentukan adalah sebesar $6.0 \mathrm{r}-60 \mathrm{y}$ dan pada uju warna pada penggorengan ikan hanya memenuhi standar pada penggorengan ke-1 saja, untuk penggorengan ke-2 dan ke-3 sudah tidak memenuhi standar lagi. Sedangkan pada tempe, penggorengan ke-1 dan ke-2 masih memenuhi standar tetapi pada penggorengan ke-3 sudah tidak memenuhi standar lagi.

Dari hasil percobaan ini terlihat bahwa minyak goreng yang dipakai berulang beberapa kali akan tidak memenuhi standar dan hal ini mengindikasikan bahwa kemungkinan minyak goreng tersebut telah mengalami kerusakan. Beberapa hal yang bisa mengakibatkan kerusakan antara lain :

- Proses Oksidasi ; oksidasi minyak sehingga mengeluarkan senyawa aldehida, keton, hidrokarbon, alkohol, lakton, serta senyawa aromatis yang mempunyai bau tengik dan rasa getir.

- Polimerisasi ; pembentukan senyawa polimer selama proses menggoreng terjadi karena reaksi polimerisasi adisi dari asam lemak tidak jenuh. Hal ini terbukti dengan terbentuknya bahan menyerupai gum yang mengendap di wadah penggorengan. Proses polimerisasi ini mudah terjadi pada minyak setengah mengering atau minyak mengering karena minyak tersebut mengandung asam-asam lemak tak jenuh dalam jumlah besar.

- Pemanasan suhu tinggi

\section{KESIMPULAN}

Penggunaan minyak goreng secara berulang bisa menyebabkan turunnya kualitasminyak goreng. Penurunan ini bisa dilihat dari analisa FFA dan warna, dimana ternyata setelahpenggorengan ke-3 nilai FFA dan warna semakin meningkat yang mengindikasikan bahwa minyak goreng tersebut 
tidak memenuhi standar yang ditentukan. Hal ini terkait dengan terjadinya reaksi oksidasidan polimerisasi yang terjadi pada minyak goreng selama proses penggorengan terutama pada penggorengan berulang pada suhu tinggi.

\section{DAFTAR PUSTAKA}

Aminah, S., dan Isworo T.J. 2009. Praktek Penggorengan dan Mutu Minyak Goreng Sisa pada Rumah Tangga Rt.05 Rw. III Kedungmundu Tembalang Semarang. Laporan penelitian Internal UNIMUS Tahun 2009.

Bangun, D, Memoar “Duta Besar” Sawit Indonesia, Jakarta: Penerbit Buku Kompas, 2010.

Departemen Perindustrian Republik Indonesia (SNI 013741 1995)

Ketaren, S. 1986. Minyak dan Lemak Pangan, Penerbit Universitas Indonesia (UI Press), Jakarta.1986.

Mulasari, A.S., \& Utami, R.R. 2012. Kandungan Peroksida pada Minyak Goreng di Pedagang Makanan Gorengan Sepanjang Jalan Prof. Dr. Soepomo Umbulharjo Yogyakarta. Arc. Com. Health. Vol. 1 No. $2: 120-123$.

Prasetyawan, E.A. 2007. Uji Kualitas Minyak Goreng Pada Para Penjual Gorengan di lingkungan Kampus Universitas Jember. http://digilib.unej.ac.id. Diakses 13 Nopember 2008,

Retno, G, Radikal bebas-sifat dan peran dalam menimbulkan kerusakan-kematian sel, Cermin Dunia Kedokteran 102, 1995.

Yoon, Y., and Choe, E. 2007. Oxidation of Corn Oil During Frying of Soy-Flour-Added Flour Dough. Journal of Food Science. Vol 72, Nr.6, Institut of Food Technologists. 